2019

\title{
Race-Conscious Admissions, Diversity, and Academic Freedom
}

Vinay Harpalani

University of New Mexico - School of Law

Follow this and additional works at: https://digitalrepository.unm.edu/law_facultyscholarship

Part of the First Amendment Commons, and the Law and Race Commons

\section{Recommended Citation}

Vinay Harpalani, Race-Conscious Admissions, Diversity, and Academic Freedom, 22 Journal of Constitutional Law Online 101 (2019).

Available at: https://digitalrepository.unm.edu/law_facultyscholarship/789

This Article is brought to you for free and open access by the UNM School of Law at UNM Digital Repository. It has been accepted for inclusion in Faculty Scholarship by an authorized administrator of UNM Digital Repository. For more information, please contact amywinter@unm.edu, Isloane@salud.unm.edu,sarahrk@unm.edu.

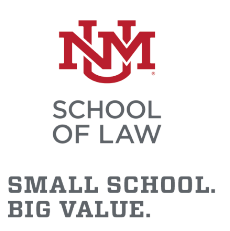

BIG VALUE. 


\title{
RAGE-CONSGIOUS ADMISSIONS, DIVERSITY, AND ACADEMIC FREEDOM
}

\author{
Vinay Harpalani*
}

For the last 40 years, race-conscious university admissions policies have been perhaps the most litigated constitutional issue before the U.S. Supreme Court. In that time, the Court has considered five cases on the merits: Regents of the University of California v. Bakke (1978) ${ }^{1}$; Gratz v. Bollinger (2003) ${ }^{2}$; Grutter v. Bollinger (2003)3; Fisher v. Texas (Fisher I) (2013)4; and Fisher v. Texas (Fisher II) (2016). ${ }^{5}$ Two other lawsuits, one against Harvard University and the other against the University of North Carolina-Chapel Hill, are now in the lower federal courts. ${ }^{6}$ These cases could potentially reach the Supreme Court by the early 2020s.

\footnotetext{
* Associate Professor, University of New Mexico School of Law. I am grateful to Destinee Andrews and Tianna Bias for their valuable research assistance. Additionally, Sarah Zeigler, former Access Services Librarian at Savannah Law School, and Heather Campbell, Public Services Associate at the Drake University Law Library, helped to track down various sources for me. Also, I thank Owen Alderson and the staff of the University of Pennsylvania Fournal of Constitutional Law for their helpful edits and suggestions. This Essay derives from scholarly work I did at three different law schools: Savannah Law School, Drake University School of Law, and the University of New Mexico School of Law. I am appreciative that all three schools provided a supportive atmosphere for my scholarship.

438 U.S. 265 (1978) [hereinafter Bakke].

539 U.S. 244 (2003) [hereinafter Gratz].

539 U.S. 306 (2003) [hereinafter Grutter]

133 S. Ct. 2411 (2013) [hereinafter Fisher I].

136 S. Ct. 2198 (2016) [hereinafter Fisher II]. Additionally, the Supreme Court agreed with a District Court's ruling in Texas v. Lesage, 528 U.S. 18, 21 (1999) (per curiam) (reversing Court of Appeals' denial of summary judgement for University of Texas at Austin after it was accused of employing admissions policy that violated $14^{\text {th }}$ Amendment). Further, it did not rule on the constitutional merits in DeFunis v. Odegaard, 416 U.S. 312, 319-20 (1974) (holding petitioner's case, in which he complained that respondent discriminated against him on account of his race in violation of Equal Protection Clause, as moot due to imminence of his graduation from same school which had initially denied him admission).

6 Students for Fair Admissions, Inc. v. President and Fellows of Harvard College, No. 14-cv-14176ADB, 2019 WL 4786210, at*1 (D. Mass. Sept. 20, 2019), appeal docketed, No. 19-2005 (1 ${ }^{\text {st }}$ Cir. Oct. 11, 2019); Students For Fair Admissions, Inc., v. University of North Carolina et al., No. 1:14CV954, 2019 WL 4773908 at*1 (M.D.N.C. Sept. 30, 2019) (denying parties' cross motions for summary judgement). See generally ProjeGt On Fair RePRESENTATiOn, https://www.proj ectonfairrepresentation.org/cases/ (last visited Sept. 14, 2019) (listing cases litigated by an advocacy organization dedicated to challenging "racial and ethnic classifications in state and federal courts").
} 
Supreme Court rulings on race-conscious admissions have focused on the Fourteenth Amendment. ${ }^{7}$ However, there is also an important First Amendment component to race-conscious admissions policies. These policies reflect a core First Amendment value: academic freedom. This Essay illustrates that there are two different ways that race-conscious admissions policies promote academic freedom. First, a university's selection of its own student body is itself an aspect of academic freedom. Second, by facilitating the admission of a more diverse student body, race-conscious admissions policies contribute to another aspect of academic freedom: the "marketplace of ideas" on campus.

Justice Felix Frankfurter laid out the basic judicial framework for universities' academic freedom under the First Amendment. His widelycited 1957 concurrence in Sweezy v. New Hampshire listed "the four essential freedoms":

It is the business of a university to provide that atmosphere which is most conducive to speculation, experiment and creation. It is an atmosphere in which there prevail 'the four essential freedoms' of a university - to determine for itself on academic grounds who may teach, what may be taught, how it shall be taught, and who may be admitted to study. ${ }^{8}$

The language here was not central to the Sweezy ruling, but the Court has often cited it when discussing academic freedom.

In particular, the fourth "essential freedom" to choose "who may be admitted to study" has taken on wider significance. Race-conscious admissions policies are in one sense rooted in this freedom. In his highly influential controlling opinion in Regents of the University of California v. Bakke (1978), Justice Lewis Powell opined that:

Academic freedom, though not a specifically enumerated constitutional right, long has been viewed as a special concern of the First Amendment. The freedom of a university to make its own judgments as to education includes the selection of its student body. ${ }^{9}$

Justice Powell held that universities could use race as a "plus factor" in admissions, so long as they did not set aside a specific number of seats for

7 Bakke and Gratz also involved Title VI of the Civil Rights Act of 1964, and SFFA v. Harvard also centers on Title VI. See Civil Rights Act of 1964, 42 U.S.C. $§ 2000 d$ (2012) ("No person in the United States shall, on the ground of race, color, or national origin, be excluded from participation in, be denied the benefits of, or be subjected to discrimination under any program or activity receiving Federal financial assistance."). Further, mootness was the primary issue in DeFunis, 416 U.S. at 319-320, and standing was a significant issue in both Fisher cases. See, e.g., Transcript of Oral Argument at 3-4, 7, 55, 73-74, Fisher I, 133 S. Ct. 2411 (2013) (No. 11-345); Transcript of Oral Argument at 35-38, Fisher II, 136 S. Ct. 2198 (2016) (No. 14-981).

8 Sweezy v. New Hampshire, 354 U.S. 234, 263 (1957) (Frankfurter, J., concurring) (citing AlBERT VAN DE SANDT CENTLIVReS ET AL., The Open Universities IN SOUTH AFriCa 11-12 (1957)) (emphasis added).

$9 \quad$ Bakke, 438 U.S. at 312 (Powell, J., concurring) (emphasis added). 
minority applicants. ${ }^{10}$ No other Justice joined Justice Powell's opinion in Bakke, but his view gained a majority on the Supreme Court in Grutter $v$. Bollinger (2003). Justice Sandra Day O’Connor's Grutter majority opinion cited and affirmed Justice Powell's concurrence, noting that "universities occupy a special niche in our constitutional tradition"-one that "recogniz [es] a constitutional dimension, grounded in the First Amendment, of educational autonomy."11 Grutter held that this autonomy allowed universities to use race-conscious policies to attain the educational benefits of diversity - which Grutter ruled was a compelling state interest. ${ }^{12}$ This holding was later affirmed in Fisher $I^{13}$ and Fisher II. ${ }^{14}$

The Court has not explicitly stated the limits of the fourth "essential freedom", but its equal protection rulings embody some of those limits. ${ }^{15}$ In Bakke, the Court rejected racial set-asides which guaranteed a particular number or percentage of admissions slots to members of underrepresented minority groups. ${ }^{16}$ Also, in Gratz v. Bollinger, the Justices struck down a mechanical point system which awarded a set number of points to all members of particular minority groups. ${ }^{17}$ In Grutter however, the Court ruled that a holistic admissions plan was narrowly tailored and thus constitutional. ${ }^{18}$ The Grutter plan employed individualized review of applicants and used race in a flexible manner, in conjunction with other aspects of an individual's application. ${ }^{19}$ So long as universities used such a plan to individually assess applicants' contribution to the educational benefits of diversity, it was constitutional. All of these are judicial limits imposed on the fourth "essential freedom."

10 Id. at 315-317 (arguing that, to be narrowly tailored, a race-conscious admissions program cannot use a quota system, but instead, may consider race or ethnicity only as a "plus" in a particular applicant's file, without "insulat [ing] the individual from comparison with all other candidates for the available seats.").

11 Grutter, 539 U.S. at 329.

Id. at 343 .

133 S. Ct. at 2419

136 S. Ct. at 2208

In addition to race, the Court has considered single gender institutions. For example, in U.S. v. Virginia, the Supreme Court struck down the Virginia Military Institute's male-only admissions policy. 518 U.S. 515, 519 (1996). Earlier, in Mississippi University for Women v. Hogan, the Court also struck down a female-only admissions policy. 458 U.S. 718, 733 (1982).

16 See Bakke, 438 U.S. at 319-320 (Powell, J., concurring) (noting that " $[\mathrm{t}]$ he fatal flaw in petitioner's preferential program is" that some racial groups are "totally excluded from a specific percentage of the seats in an entering class.").

17 Gratz, 539 U.S. at 271 (holding that a "policy [which] automatically distributes 20 points to every single applicant from an 'underrepresented minority' group" violates Fourteenth Amendment). Grutter, 539 U.S. at 343. Id. at 337 . 
But what about limits from the states? In the wake of Grutter, Professor J. Peter Byrne argued that "Grutter clarified that academic freedom is a real constitutional right ...."20 Professor Byrne suggested that any state law that prevents a university from considering race in admissions is unconstitutional as a violation of the First Amendment. ${ }^{21}$ However, a First Amendment right is a proscription on state action, and Professor Byrne acknowledged that possession of such a right by a public university - which is itself a part of the state - is "surprising" and "peculiar." 22

In fact, states have limited university admissions policies by various means. State constitutional amendments, enacted through popular referendum, are one example. Several states have passed state constitutional bans on race-conscious policies in this manner: California (1996), Washington (1998), Michigan (2006), Nebraska (2008), Arizona (2010), and Oklahoma (2012). ${ }^{23}$ Michigan's ban was challenged, but in Schuette v. Coalition to Defend Affirmative Action (2014), the Supreme Court upheld it. ${ }^{24}$ Justice Kennedy's majority opinion noted that Schuette "is not about how the debate about racial preferences should be resolved ... [i] t is about who may resolve it."25 Despite the First Amendment-based "essential freedom" of universities to choose their own student bodies, the parties litigated Schuette solely on Fourteenth Amendment grounds. ${ }^{26}$ The only mention of First Amendment rights in Schuette was the freedom of the voters who voted on the ban. ${ }^{27}$

States can also ban race-conscious admissions policies via legislative action. In 2011, New Hampshire's state legislature passed a state law banning such policies. ${ }^{28}$ Texas's Top Ten Percent Law, which was at the

20 J. Peter Byrne, Constitutional Academic Freedom After Grutter: Getting Real About the "Four Freedoms" of a University, 77 U. COLO. L. REV. 929, 934 (2006).

21 Id. at 937 ("From my reading of Grutter, strong arguments arise that any state law that bars the use of race in state university admissions violates constitutional academic freedom.").

22 Id. at 938 (noting that state university is government apparatus but is also afforded First Amendment rights protecting it from government).

23 See generally Dominique J. Baker, Why Might States Ban Affirmative Action, BroOKINGs INSTITUTION, Apr. 12, 2019, https://www.brookings.edu/blog/brown-center-chalkboard/2019/04/12/whymight-states-ban-affirmative-action/ (mapping American states that banned affirmative action between 1996 and 2012).

24572 U.S. 291, 314-15 (2014) ("There is no authority in the Constitution of the United States or in this Court's precedents for the Judiciary to set aside Michigan laws that commit this policy determination to the voters.").

25 Id. at 314.

26 Id. at 298 ("The Court ... must determine whether an amendment to the Constitution of the State of Michigan ... is invalid under the Equal Protection Clause of the Fourteenth Amendment .....”).

27 Id. at 312-13 ("It is the right to speak and debate and learn and then, as a matter of political will, to act through a lawful electoral process.").

28 H.R. 0623, 2001 Sess. (N.H. 2011) (enacted) (prohibiting "preferences in recruiting, hiring, promotion, or admission by state agencies, the university system, the community college system, and the postsecondary education commission."). 
heart of the controversy in Fisher I and Fisher II, significantly curbs Texas public universities' autonomy to determine which students are admitted to study. ${ }^{29}$ This law guarantees admission to all public universities in Texas to the top students in all Texas high schools. ${ }^{30}$ It essentially allows the state legislature to determine a large percentage of Texas public universities' student bodies. Other states have also adopted similar plans. ${ }^{31}$

Additionally, Florida Governor Jeb Bush eliminated race-conscious policies by executive order ${ }^{32}$ - a ban that is still in place. Thus, all three branches of government can curb universities' fourth "essential freedom."

First Amendment challenges to any of these actions would almost certainly fail under Schuette. So how much autonomy do universities have to determine their own student bodies? In Bakke, Justice Powell stated that the fourth "essential freedom" is "not a specifically enumerated constitutional right" but rather "a special concern of the First Amendment." "33 Through Bakke, Grutter, and Fisher, the Court has held that the First Amendment's "special concern" with academic freedom is a limited principle of judicial deference. Within the context of race-conscious admissions, the Supreme Court has consistently held that courts should give deference to universities in defining their educational missions. Justice Powell's Bakke opinion first noted the principle of judicial deference in the context of race-conscious admissions policies:

Universities ... may make individualized decisions, in which ethnic background plays a part, under a presumption of legality and legitimate educational purpose. So long as the university proceeds on an individualized, case-by-case basis, there is no warrant for judicial interference in the academic process. ${ }^{34}$

29 TEX. EDUC. CODE ANN. § 51.803 (1997) (“[E] ach general academic teaching institution shall admit an applicant for admission to the institution as an undergraduate student if the applicant graduated with a grade point average in the top 10 percent of the student's high school graduating class in one of the two school years preceding the academic year for which the applicant is applying for admission .....”.

$30 \quad I d$.

31 See generally Richard D. Kahlenberg, A Better Affirmative Action: State Universities that Created Alternatives to Racial Preferences, CENTURY FOUNDATION 26-61 (2012), https://productiontcf.imgix.net/app/uploads/2012/10/03175956/tcf_abaa-8.pdf (describing the affirmative action policies of California, Washington, Florida, Georgia, Michigan, Nebraska, Arizona, and New Hampshire).

32 Fla. Exec. Order No. 99-281 (1999) ("I hereby request that the Board of Regents implement a policy prohibiting the use of racial or gender set-asides, preferences or quotas in admissions to all Florida institutions of higher education effective immediately.").

33 Bakke, 438 U.S. at 312 (Powell, J., concurring) (quoting Keyishian v. Board of Regents, 385 U.S. 589, $603(1967))$.

34 Id. at 319 n.53. 
Subsequently, in Grutter, Justice O'Connor's majority opinion held that:

The Law School's educational judgment that such diversity is essential to its educational mission is one to which we defer. [...] Our holding today is in keeping with our tradition of giving a degree of deference to a university's academic decisions, within constitutionally prescribed limits . . . . "[G]ood faith" on the part of a university is "presumed" absent "a showing to the contrary." 35

Fisher I reiterated this holding in part, in a majority opinion by Justice Anthony Kennedy. The scope of this principle of judicial deference was the only issue decided by the Court in Fisher I. With an unexpected 7-1 ruling, Fisher I reiterated Grutter's holding that the courts should, within limits, defer to universities' academic decisions. ${ }^{36}$ Fisher I also made clear that a university "receives no deference" from the reviewing court on whether the "means chosen by the $[\mathrm{u}]$ niversity to attain diversity are narrowly tailored. . . ." 37 Fisher II did not alter this framework: it merely held that the University of Texas at Austin's race-conscious admissions policy was narrowly tailored. ${ }^{38}$

These cases indicate that the fourth "essential freedom" is a First Amendment-based principle of limited judicial deference, not a full-fledged right. Courts defer to a university's "good faith" assertion that diversity has educational benefits which promote the university's mission. As noted by Professor Paul Horwitz, a "natural reading of the Court's opinion in Grutter suggests that, far from deferring to the general expertise of academic officials, the Court here was actively endorsing the educational benefits of diversity." 39 Because attaining these benefits is a compelling state interest, the fourth "essential freedom" here is essentially universities' freedom to use race as an admissions factor to attain them, subject to narrow tailoring limits.

But the compelling interest in diversity is a significant exception in the Supreme Court's current race-based equal protection jurisprudence. Supreme Court rulings on race have generally espoused an anti-classification principle - one that strongly disfavors any racial classifications. ${ }^{40}$

35 Grutter, 539 U.S. at 328-29 (quoting Bakke, 438 U.S., at 318-319).

36 See Fisher I, 133 S. Ct. at 2419 (quoting Grutter, 539 U.S. at 328) (explaining that some, but not complete, judicial deference is proper regarding Universities' statements of their educational mission and subsequent enrollment policies).

37 Id. at 2420

38 Fisher II, 136 S. Ct. at 2214 (2016).

39 Paul Horwitz, Grutter's First Amendment, 46 B.C. L. REV. 461, 499 (2005).

40 See Jack M. Balkin \& Reva B. Siegel, The American Civil Rights Tradition: Anticlassification or Antisubordination?, 58 U. Miami L. Rev. 9, 9-10 (2003) (citing Owen M. Fiss, Groups and the Equal Protection Clause, 5 PHIL. \& PUB. AFF. 107 (1976)) (defining antisubordination as the principle "that law should reform institutions and practices that enforce the secondary social status of historically oppressed groups[,]" and defining anticlassification as principle "that the government may not classify people either overtly or surreptitiously on the basis of a forbidden category .....”). 
Colorblindness, rather than race-consciousness, is preferred unless strict scrutiny is met. Grutter and the other affirmative action cases thus invoke a constitutional conflict: a choice between the First Amendment's "special concern" with universities' academic freedom and the Fourteenth Amendment's proscription on government use of race. In this context, the question is, why has the Supreme Court favored universities' academic freedom to admit a diverse student body over the colorblind ideal of current equal protection doctrine? As put by Justice Clarence Thomas, why has the Court created a "First Amendment . . . basis for . . . universities to do what would otherwise violate the Equal Protection Clause"?41

This Essay argues that the reason lies not only in fourth "essential freedom," but also in the nature of diversity itself. Diversity encompasses another aspect of academic freedom, because diversity within a student body enhances the "marketplace of ideas" on campus, and this enhances student learning.

The marketplace of ideas notion harks back to the origins of academic freedom, well before Justice Frankfurter's Sweezy concurrence. Professor Robert Post describes how academic freedom emerged from the First Amendment to protect a marketplace of ideas that "produces knowledge." 42 In 1919, Justice Oliver Wendell Holmes' dissent in Abrams v. United States (1919) asserted that "free trade in ideas" was the best path to "truth," via "competition in the market" and "experiment." 43 The marketplace of ideas is the notion that academic freedom should allow free exchange of ideas, similar to goods and services in the economy. ${ }^{44}$ While the goal of traditional economic exchange is typically profit or value gain, the purpose of a free market of ideas is to discover the "truth." 45 The First Amendment's protection of speech allows the free exchange of ideas, and the "special concern" with academic freedom relates the important function of universities (and the scholars within them) to discover the "truth."46

Future Supreme Court decisions adopted Justice Holmes' ideas. For example, in Red Lion Broad. v. FCC (1969), the Court noted that "it is the purpose of the First Amendment to preserve an uninhibited marketplace of ideas in which truth shall ultimately prevail ...." 47 The marketplace of ideas

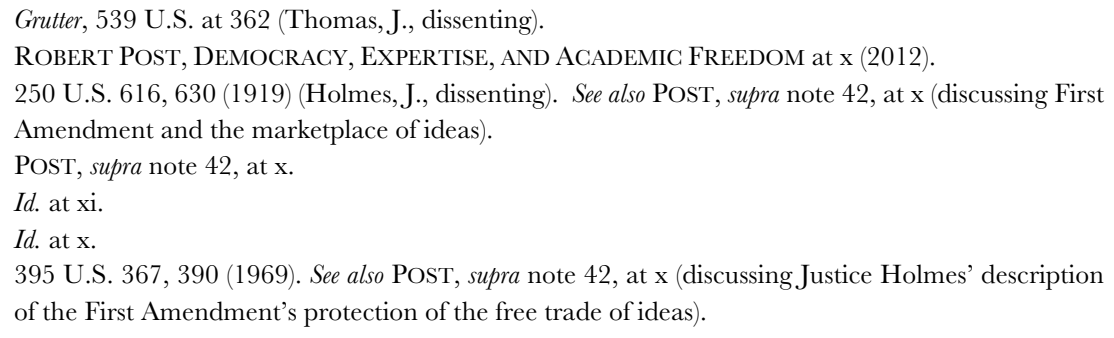


notion has been widely critiqued, ${ }^{48}$ but it has unquestionably influenced First Amendment jurisprudence on academic freedom. ${ }^{49}$

Traditionally, discourse on academic freedom and the marketplace of ideas has emphasized "freedom of inquiry" to conduct research and exchange ideas. ${ }^{50}$ This discourse focuses on exchanges between scholarsusually experts in a given field. ${ }^{51}$ However, the marketplace notion also extends to exchanges between faculty and students, and between students themselves. The Supreme Court has recognized this, beginning with its majority opinion in Keyishian v. Board of Regents (1967): "[t]he classroom is peculiarly the "marketplace of ideas." "52 Healy v. Fames (1972) applied this idea specifically to higher education: "[ $\mathrm{t}]$ he college classroom with its surrounding environs is peculiarly the "marketplace of ideas," 53 where the purpose is not merely to transmit knowledge, but to develop critical thinking skills necessary to produce knowledge. ${ }^{54}$ This is true not only of classrooms, ${ }^{55}$ but of all venues and activities on campus. ${ }^{56}$

Diversity among students is key to a thriving marketplace of ideas in the classroom and on campus generally. Such a marketplace must include students with different experiences and perspectives. When Justice Powell discussed diversity in Bakke, he tied its educational benefits to the "safeguarding [of] academic freedom" through the "robust exchange of ideas[.]" $57 \mathrm{He}$ added that an "atmosphere of 'speculation, experiment and creation' - so essential to the quality of higher education - is widely believed to be promoted by a diverse student body." 58 Bakke thus directly tied diversity

48 This Essay argues that the major critiques of the "marketplace of ideas" apply to the production of scholarship, not to student learning. See infra text accompanying notes 69-76.

49 See, e.g., POST, supra note 42, at x-xi (noting the Supreme Court's frequent invocation of First Amendment principles to support a marketplace of ideas and debate on public issues).

50 See id. at 65 (listing "freedom of inquiry and research" as necessary element of academic freedom).

51 See $i d$. at xi-xii (discussing contradiction inherent in applying the marketplace of ideas notion to expert knowledge).

52 Keyishian, 385 U.S. at 603.

53 Healy v. James, 408 U.S. 169, 180 (1972) (quoting Keyishian, 385 U.S. at 603) (holding that state college could not deny official recognition of student group under the First Amendment).

54 Sheldon H. Nahmod, Controversy in the Classroom: The High School Teacher and Freedom of Expression, 39 GEO. WASH. L. REV. 1032, 1032 (1971).

55 Having diversity of perspectives and experiences may be more appropriate and beneficial in some classes than in others. For example, science and math classes often tend towards one correct answer, whereas those in the humanities focus more on having various perspectives and different interpretations of phenomena.

56 See Vinay Harpalani, "Safe Spaces" and the Educational Benefits of Diversity, 13 DukE J. ConsT. L. \& PUBLIC POL'Y 117, 152 (2017) (discussing educational importance of diversity within the classroom as well as other settings on college campuses).

57 Bakke, 438 U.S. at 312 (quoting Keyishian, 385 U.S. at 603).

$58 \quad$ Id. 
to the values inherent in the marketplace of ideas - and thus to the virtues of academic freedom.

Twenty-five years after Bakke, Justice Sandra Day O'Connor's majority opinion in Grutter linked these educational benefits to race-conscious admissions policies aimed at admitting a "critical mass" 59 of underrepresented minority students:

[C]ritical mass is defined by reference to the educational benefits that diversity is designed to produce. These benefits are substantial . . . . [and include] . . promot[ing] "cross-racial understanding," help[ing] to break down racial stereotypes, and "enable[ing] [students] to better understand persons of different races." These benefits are "important and laudable," because "classroom discussion is livelier, more spirited, and simply more enlightening and interesting" when the students have "the greatest possible variety of backgrounds." 60

Justice O'Connor further noted that "when a critical mass of underrepresented minority students is present, racial stereotypes lose their force because nonminority students learn there is no 'minority viewpoint' but rather a variety of viewpoints among minority students." 61 Justice O'Connor thus applied the marketplace notion to the "variety of viewpoints" among minority students, ${ }^{62}$ and Fisher $I$ and $I I$ affirmed this view. ${ }^{63}$

Grutter also cited social science studies that illustrated the links between diversity and the marketplace of ideas on campus. The amicus brief of the American Educational Research Association et al. noted that student body diversity can "challenge students to consider alternative viewpoints." 64

59 Grutter, 539 U.S. at 330 (holding University of Michigan Law School's affirmative action policy constitutional under Equal Protection Clause and discussing benefits of diversity at the law school).

$60 \quad I d$. (last alteration in original) (citations omitted).

61 Id. at 319-20 (emphasis added) (citation omitted).

62 Justice O'Connor also highlighted the long-term benefits of diversity for national and global leadership. See Grutter, 539 U.S. at 308 ("[M]ajor American businesses have made clear that the skills needed in today's increasingly global marketplace can only be developed through exposure to widely diverse people, cultures, ideas, and viewpoints."); Id. at 331 ("[H]igh-ranking retired officers and civilian leaders of the United States military assert that, '[b]ased on [their] decades of experience,' a 'highly qualified, racially diverse officer corps ... is essential to the military's ability to fulfill its principle mission to provide national security."') (citation omitted) (alternation in original).

63 See, Fisher I, 133 S. Ct. at 2418 ("The attainment of a diverse student body . . serves values beyond race alone, including enhanced classroom dialogue and the lessening of racial isolation and stereotypes."); Fisher II, 136 S. Ct. at 2210 ("enrolling a diverse student body "promotes cross-racial understanding, helps to break down racial stereotypes, and enables students to better understand persons of different races."') (quoting Grutter, 539 U.S. at 328).

64 Brief of Am. Educ. Research Ass'n et al. as Amici Curiae Supporting Respondents at 3, Grutter v. Bollinger, 539 U.S. 244 (2003) (No. 02-041). Other studies cited in Grutter also supported this notion. See, e.g., Gary Orfield, Introduction to Diversity CHALLENGED: EvidENCE ON THE IMPACT Of AfFirmative ACTiON 1, 15 (Gary Orfield \& Michal Kurlaender, eds., 2001) ("There is powerful evidence to show that admitting minority students is likely to bring onto the campus 
Additionally, a study by Professor Gary Orfield and Dean Whitla noted that "interactions with diverse peers (in terms of race, interests, and values)" led to "a greater openness to diverse perspectives and a willingness to challenge their own beliefs of the first year of college." 65

Beyond its articulation of the compelling interest in diversity, the Supreme Court's narrow tailoring principles for race-conscious admissions also reinforce the educational value of different perspectives. In order to be narrowly tailored, Bakke and Grutter require that a race-conscious admissions policy applies flexible, individualized review, with race as one factor among many. ${ }^{66}$ Such a policy promotes the educational benefits of diversity because unlike the policies rejected in Bakke and Gratz, it involves assessment of the different perspectives and experiences that each individual applicant can contribute. This relates directly to the "variety of viewpoints" among minority students referenced by Justice O'Connor. ${ }^{67}$

Also, at the Fisher I oral argument, Solicitor General Donald Verrilli, arguing in support of the University of Texas race-conscious admissions policy, took this one step further, noting how such a policy could actually target minority students who defy racial stereotypes:

Universities ... are looking ... to make individualized decisions about applicants who will directly further the education mission .... [f]or example, they will look for individuals who will play against racial stereotypes .... [t] he African American fencer; the Hispanic who has ... mastered classical Greek. 68

The enrollment of such students would expose nonminority students to different perspectives within each minority group, thus contributing to the educational benefits of diversity and expanding the marketplace of ideas.

students with different worldviews and experiences that can enrich the discussions and exchanges ... that are so important to a good college education."); Sylvia Hurtado, Linking Diversity and Educational Purpose: How Diversity Affects the Classroom Environment and Student Development, in DIVERSITY ChalleNGED: EVIDENCE ON THE IMPACT OF AFFirmative ACTION, supra, at 187, 189 (citing Ernest T. Pascarella et al., Influences on Students' Openness to Diversity and Challenge in the First Year of College, 67 J. Higher EDUC. 174, 188 (1996)).

65 Gary Orfield \& Dean Whitla, Diversity and Legal Education: Student Experiences in Leading Law Schools, in Diversity CHALLENGED: EVIDENCE ON THE IMPACT OF AFFIRMATIVE ACTION, supra note 64 at 189 (citation omitted). Grutter also highlighted the long-term societal benefits of exposing students to diverse experiences and perspectives. 539 U.S. at 308 (" $[\mathrm{T}]$ he skills needed in today's increasingly global marketplace can only be developed through exposure to widely diverse people, cultures, ideas, and viewpoints.").

66 See Grutter, 539 U.S. at 334 ("To be narrowly tailored, a race-conscious admissions program cannot use a quota system ... [it] must be 'flexible enough to consider all pertinent elements of diversity in light of the particular qualifications of each applicant ...."') (quoting Bakke, 438 U.S. at 317).

67 Grutter, 539 U.S. at 320.

68 Transcript of Oral Argument at 61, Fisher v. Univ. of Tex. at Austin, 133 S. Ct. 2411 (2013) (No. 11-345). 
Many academic commentators have critiqued the marketplace of ideas on various grounds. This Essay argues that while these critiques may be valid in the context of free speech and production of scholarship, they are largely inapplicable to diversity and student learning.

Perhaps the major critique is that the marketplace does not lead to "truth" as originally posited by Justice Holmes. ${ }^{69}$ Professor Stanley Ingber has argued that "truth," if and when it exists at all, is not necessarily attained through such a process: there may be no agreement and an idea's validity might not translate into its success or acceptance in a competitive market. ${ }^{70}$ This critique may be valid with respect to academic scholarship, where in consensus may be desirable in some disciplines. However, with respect to student learning and diversity, the goal is not to find "truth" per se. Rather, the purpose of the marketplace is to give students exposure to various perspectives on a range of issues, and to expose them to new issues that they have not thought about before._As Professor Paul Horwitz notes, the Supreme Court in Keyishian suggested that academic freedom was valuable not only as a "search for truth," but also for "the training and shaping of the nation's citizens." 71 The process of engaging different ideas is itself valuable because the goals for students are not finding "truths" per se, but rather: 1) Appreciation of different viewpoints from people with different experiences; 2) Development of critical thinking skills; 3) Ability to solve novel problems that arise in the course of their professional and civic activities; and 4) Preparation for global leadership. ${ }^{72}$

As such, in the context of student learning and especially of diversity, the purpose of the marketplace of ideas is, in some sense, the opposite of what Justice Holmes espoused. Rather than finding "truth," the goal is to make students question the "truths" that they hold and to be able to see and understand the different "truths" that others hold. 73

Scholars have also argued that contrary to Justice Holmes' ideal, academia functions mainly to exclude ideas, not to include them. Ideas that

69 See Stanley Ingber, The Marketplace of Ideas: A Legitimizing Myth, 1984 DukE L.J. 1, 27 (1984)

("Conflicts in the marketplace, therefore, are not likely to lead to conclusive agreement on what is 'true' or 'best.").

70 Id. at 31 (arguing that "the marketplace assumption of objective truth is implausible.").

71 Horwitz, supra note 39, at 489.

72 Cf. generally Harpalani, supra note 56, at 150, 152-55 (discussing how educational benefits of diversity occur in "safe spaces"); Devon Carbado, Intraracial Diversity, 60 UCLA L.REv.1130, 1145-46 (2013) (discussing eight values promoted by diversity as advanced by Grutter opinion).

73 See, e.g., Vinay Harpalani, "Gifted with a Second-Sight": Professor Derrick Bell the Teacher, in CovenanT KEEPER: DeRrick Bell's ENDURING EDUCATION Legacy 17, 28 (Gloria J. Ladson-Billings \& William F. Tate eds., 2016) (noting how Professor Derrick Bell's "focus in class was getting students to understand different versions of the 'truth' ...."). 
are not well supported or inapposite must be excluded for an efficient market and productive debate._Professor Robert Post notes the discord between the AAUP definition of academic freedom, which focuses on professional norms and expert knowledge, and the marketplace notion, which embraces ideas from all sources. ${ }^{74}$ Experts produce scholarship which often narrows the scope of ideas rather than expanding it. In fact, one of the main functions of scholars is to include and exclude people (and thus ideas) from the circles of experts in their respective disciplines.

In one sense, this critique is also applicable to a university's fourth "essential freedom." Elite universities in particular are very selective about the students they admit, in part because their academic reputations depend on the achievement profiles of their students. However, race-conscious admissions policies serve to reduce this exclusivity in admissions. The pursuit of diversity leads to the inclusion of less common perspectives. While exclusion of ideas may be needed for expertise and advancement of disciplinary knowledge, diversity promotes the goal of student learning through broad inclusion of ideas.

Additionally, Professor Ingber has contended that the marketplace notion emphasizes expression of different ideas at the expense of different experiences which actually lead to these different ideas. ${ }^{75} \mathrm{He}$ contends that marketplace notion confuses the dependent (expression) and independent (experience) variables. ${ }^{76}$ The compelling interest in diversity addresses this concern directly. The pursuit of diversity in university admissions relies on different experiences to produce different ideas. ${ }^{77}$ Moreover, the relationship between expression and experience is cyclical. Exposure to different perspectives is itself an experience that leads students to form new ideas and view the world in new ways, which again prompts them to seek new experiences. Through this process, diversity promotes learning and adaptability through exposure and experience. ${ }^{78}$

74 Post, supra note 42, at 66-68.

75 Ingber, supra note 69, at 86 ("A diversity of perspectives first requires a corresponding diversity of social experiences and opportunities.").

76 Id. at 76 ("To focus on diversity of expression rather than diversity of experience is to focus on the dependent rather than the independent variable. Yet the dominance of the market model and conventional theories of the first amendment demonstrate our nation's emphasis on free expression.").

77 Cf. Elise C. Boddie, Critical Mass and the Paradox of Colorblind Individualism in Equal Protection, 17 U. PA. J. CONST. L. 781, 815 (2015) (" $[\mathrm{U}]$ niversities need only show that their policies seek to admit students of color with a range of different experiences and that these policies are narrowly tailored to their goals.").

78 See Vinay Harpalani, Diversity and Living Constitution Theory, ACS BloGS: ExPERT FORUM (Sept. 15, 2015), https://www.acslaw.org/expertforum/diversity-and-living-constitution-theory/ (discussing the potential role of "living Constitution" in evolving legality of race-conscious policies). The idea 
All of these critiques illustrate that applicability of the marketplace of ideas to diversity and student learning is on significantly firmer ground than it is for free speech and scholarship.

Race-conscious admissions policies may also implicate other First Amendment issues. SFFA v. Harvard aims to eliminate not only consideration of race in admissions, but also all references to race on university applications. ${ }^{79}$ If this remedy is adopted by a public university, one could argue that it violates applicants' right to freedom of expression. Also, the compelling interest that justifies race-conscious admissions is not merely attaining the educational benefits of diversity, but also maintaining those benefits. ${ }^{80}$ Otherwise, the pursuit of diversity in admissions would be pointless. In Grutter, the Supreme Court noted the need for a "critical mass" of minority students to insure that these students do not feel "isolated or like spokespersons for their race." ${ }^{\prime 1}$ Fisher I reiterated this concern, ${ }^{82}$ as minority students must feel welcomed on campus in order to be engaged and contribute their diverse perspectives to the campus marketplace. ${ }^{83}$ If it is necessary to maintain the educational benefits of diversity, universities may be able to regulate speech and activities that inhibit minority students from campus engagement. Courts have been hostile towards attempts to regulate campus hate speech, generally ruling that such regulations are violations of the First Amendment. ${ }^{84}$ Ironically, however, some regulation might actually promote academic freedom in the grand scheme, by creating campus

of adaptability through exposure is also a central theme in developmental psychology, when analyzing changing conceptions of self. See generally Margaret Beale Spencer, Dena Phillips Swanson \& Vinay Harpalani, Conceptualizing the Self, in 3 HandBook of Child Psychology AND Developmental Science 750 (Richard M. Lerner ed., 2015).

79 Elise Boddie, A Damaging Bid to Censor Applications at Harvard, N.Y. Times (Oct. 10, 2018), https://www.nytimes.com/2018/10/10/opinion/harvard-affirmative-action-lawsuit.html.

80 See Stacy L. Hawkins, A Deliberative Defense of Diversity: Moving Beyond the Affirmative Action Debate to Embrace a 21st Century View of Equality, 2 COLUM. J. RACE \& L. 75, 110 (2012) (noting that "the diversity interest may in fact entail both achieving and maintaining diversity.").

$81 \quad$ Grutter, 539 U.S. at 319.

82 Fisher I, 133 S. Ct. 2418 (recognizing "lessening of racial isolation" as one goal of race-conscious admissions policies). See also I. Bennett Capers, Flags, 48 How. L.J. 121, 123 (2004) (explaining how "critical mass" of diverse students "implies a climate where one can speak freely, where one not only has a voice, but a voice that will be heard.").

83 See generally Vinay Harpalani, "Safe Spaces" and the Educational Benefits of Diversity, 13 DUKE JOURNAL of Constitutional Law \& PUblic Policy 117 (2017) (discussing relationship between safe spaces and value of diversity in higher education).

84 See, e.g., Dambrot v. Central Michigan University, 55 F.3d 1177, 1182 (6th Cir. 1995) (holding that a campus speech code which targeted racial and ethnic harassment violated the First Amendment); see also, State of the Law: Speech Codes, FIRE (last updated 2019) https://www.thefire.org/legal/stateof-the-law-speech-codes/ (discussing cases with similar results as Dambrot). 
environment where minority students can contribute more readily to the marketplace of ideas. ${ }^{85}$

In sum, there are two prongs to the relationship between race-conscious admissions policies and academic freedom. First, these policies are themselves an expression of universities' academic freedom: Justice Frankfurter's fourth "essential freedom" of choosing "who may be admitted study." 86 Second, through their generation of diversity in the student body, race-conscious admissions policies expand the marketplace of ideas on campus and thus facilitate student learning. Accordingly, legal challenges to race-conscious admissions policies are also challenges to academic freedom, and courts should view them as such.

85 Universities can respond in other ways to campus speech that creates a hostile environment for minority students. For example, when Professor Amy Wax stated that very few if any Black students at the University of Pennsylvania Law School excel academically, the Law School barred her from teaching required first-year courses. See Madeleine Lamon, After 'Disparaging' Comments On Black Students, Amy Wax Barred From Teaching First-Year Course, Daily Pennsylvanian (Mar. 13, 2018, 6:48 PM), https://www.thedp.com/article/2018/03/penn-law-dean-ted-ruger-professor-amy-wax-re moved-racial-conservative-graduate-upenn-philadelphia_(discussing_Penn_Law Administration's response to Professor Wax's controversial remarks). More recently, Professor Wax opined that the U.S. would "'be better off with more whites and fewer non-whites."' Isaac Chotiner, A Penn Law Professor Wants to Make America White Again, New Yorker (Aug. 23, 2019), https://www.newyork er.com/news/q-and-a/a-penn-law-professor-wants-to-make-america-white-again.

86 Sweezy v. New Hampshire, 354 U.S. 234, 263 (1957) (Frankfurter, J., concurring) (quoting ALBERT VAN DE SANDT Centlivres ET AL, The Open Universities in SOUth AFrica 11-12 (1957)). 